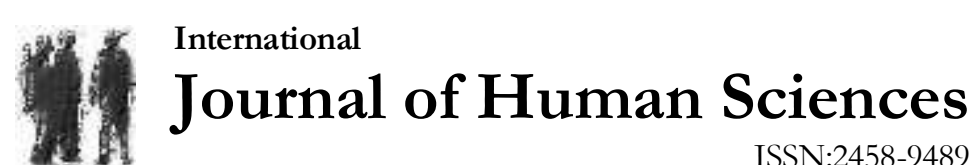

Volume 15 Issue 3 Year: 2018

\section{Foreign language learning anxiety: A comparison between high school and university students}

\author{
Gökhan Baş ${ }^{1}$ \\ Mehmet Özcan ${ }^{2}$
}

\begin{abstract}
This research aimed to identify the differences in foreign language learning (FLL) anxiety levels between high school and university students based on some variables such as gender, current educational status, parents' (father and mother) educational status, and monthly income of families. The survey model was adopted in the research. The research included high school $(n=$ $333)$ and university $(n=341)$ students from Nigde and Afyonkarahisar provinces. In the research, "Foreign Language Learning Anxiety Scale" (FLLAS) was used in order to collect data. For the analyses of the data, independent samples $t$-test and one-way ANOVA were performed. The results of the research indicated that gender, fathers' educational status and monthly income of family variables did not have a significant impact on foreign language anxiety levels of high school and university students. It was also found that students' educational status as well as their mothers' educational status variables influenced their FLL anxiety significantly.
\end{abstract}

Keywords: Foreign Language Learning; Anxiety Level; High School and University Students.

\section{Introduction}

Foreign language learning may be a challenging activity for many learners (Riasati, 2011). Besides numerous variables that make the process of learning a foreign language challenging, foreign language learning (FLL) anxiety appears to be an important one among all (Baş, 2014). It is known that many students experience anxiety in one way or another during the language learning process. According to Von Wörde (1991), more than the half of foreign language learners has FLL anxiety. In this sense, it is not surprising that a lot of learners complain about the anxiety they experience during this process (Riasati, 2011).

FLL anxiety is different from other types of anxiety due to the negative effect it has on learning process (MacIntrye \& Gardner, 1991). According to Horwitz, Horwitz, and Cope (1986), FLL anxiety is a situation-specific one. It is defined as the feeling of tension and apprehension that may impede speaking, listening in a foreign language and even learning it (MacIntyre \& Gardner, 1994). Horwitz, Horwitz, and Cope (1986) point out that FLL anxiety is a set of behaviors and a sense of self which is unique to foreign language classes and originates from the uncertainties of the process. FLL anxiety was first studied as a separate phenomenon unique to language learning by Horwitz, Horwitz, and Cope (1986). According to them, foreign language classes are anxiety provoking atmospheres for learners. It is revealed that learners may be unsuccessful due to high level of anxiety in foreign language classes though they become highly successful in other fields of

\footnotetext{
1 Assist. Prof. Dr., Niğde Ömer Halisdemir University, Faculty of Education, gokhanbas51@gmail.com

2 Assist. Prof. Dr., Nevşehir Hacı Bektaş Veli University, Faculty of Education, mehmetozcan79@,hotmail.com
} 
Baş, G., \& Özcan, M. (2018). Foreign language learning anxiety: A comparison between high school and university students. Journal of Human Sciences, 15(3), 1584-1596. doi:10.14687/ihs.v15i3.4441

study (Cheng, Horwitz, \& Shallert, 1999; MacIntyre \& Gardner, 1994). Individuals who do not have any difficulties in expressing themselves in their mother tongue, cannot do the same in a foreign language and perceive all the performances that they are expected to do as threats to their self-images. The perception of being a successful communicator as a self-image turns into tension, apprehension and even panic in foreign language learning contexts (Horwitz, Horwitz, \& Cope, 1986). Moreover, Krashen (1985) states that high anxiety level of a language learner hinders his/her her language learning process. In their study, Gardner, Day, and MacIntyre (1992) revealed that anxiety has a significantly influential role on language learning. When the relevant studies in the literature are reviewed, it can be seen that there is a significant negative correlation between anxiety level and foreign language learning achievement (e.g., Akpur, 2005; Baş, 2013a; Batumlu, 2006; Dalkılıç, 2001; Gülsün, 1997; MacIntyre \& Gardner, 1994; Oya, Manola, \& Greenwood, 2004; Öner \& Gedikoğlu, 2007; Sarigül, 2000). In other words, it can be said that as the anxiety level of a learner increases, his/her achievement level in learning a foreign language decreases. In the same vein, the study conducted by Horwitz, Horwitz, and Cope (1986) showed that individuals feel nervous, anxious and stressed in foreign language classes and they are hindered due to high level of anxiety when they want to learn a foreign language. They also argued that individuals with a high motivation and enthusiasm in the fields like science, mathematics, and music lose their motivation in the field of foreign language learning and this situation is caused by learning a language in a classroom atmosphere.

Foreign language anxiety appears in different ways. Factors such as fear of making mistakes or a perfectionist attitude while speaking can lead to this anxiety (Horwitz, Horwitz, \& Cope, 1986). In addition to many factors that provoke anxiety, language skills, especially speaking and listening, may lead to high levels of anxiety as well (MacIntyre \& Gardner, 1994; Horwitz, Horwitz, \& Cope, 1986). Besides, some other factors such as perceived inefficacy of learners compared to their peers (Bailey, 1983; Sparks \& Ganschow, 1991), negative teacher behaviors (Baş, 2014; Ellis \& Rathbone, 1987), difficulty level of language courses (Price, 1991; Young, 1990), age (Gardner, Smythe, Clément, \& Gliksman, 1976), and culture (Aydın, 1999) may cause anxiety in foreign language learning process. It was also revealed that highly anxious learners are afraid of making mistakes, being spotlighted or being laughed by their peers in language classes and they cannot communicate with their friends efficiently. Furthermore, language classes' needing preparation, students' desire to be successful in a short time, their desire to be native-like etc. may also lead them to be anxious learners (Horwitz, Horwitz, \& Cope, 1986; MacIntyre \& Gardner, 1994). Similarly, it can be suggested that some other reasons that would create anxiety among learners include speaking and listening activities, teaching methods and techniques, fear of making mistakes, learning environment, attitudes of teachers and examinations held in schools (Baş, 2014). In this sense, identifying and understanding the anxiety level of students in foreign language learning classrooms is thought to create a better and more efficient learning process.

\subsection{Aim of the research}

This research aimed to investigate the FLL anxiety levels of high school and university students according to some variables. The problem statement of the research was posed as "What is the FLL anxiety of students studying at high school and university?" The following research questions were addressed throughout the research:

1. What is the FLL anxiety level of high school and university students?

2. Does the FLL anxiety level of high school and university students differ in terms of gender, current educational status, educational status of parents (father and mother), and monthly income of families? 
Baş, G., \& Özcan, M. (2018). Foreign language learning anxiety: A comparison between high school and university students. Journal of Human Sciences, 15(3), 1584-1596. doi:10.14687/ihs.v15i3.4441

\section{Methodology}

\subsection{Research Design}

In this research, FLL anxiety level of students in three high schools in Niğde province and at the English preparatory program of Afyon Kocatepe University, School of Foreign Languages was compared in terms of some variables. For this reason, a survey model was adopted in the research (Karasar, 2005). The major purpose of survey research is to describe the characteristics of a population (Fraenkel \& Wallen, 2000).

\subsection{Participants}

The participants of the research included students $(n=674)$ in Niğde and Afyonkarahisar provinces. Of the participants, 333 students were studying in three public high schools in Niğde province and 341 students were enrolled at the English preparatory program of Afyon Kocatepe University, School of Foreign Languages.

When the demographic features of the participants were examined, it was seen that $49.40 \%$ $(n=333)$ of them are high-school students; $50.60 \%(n=341)$ are university students; $39.47 \%$ of the participants were male $(n=266)$ and $60.53 \%$ were female $(n=408)$ students.

\subsection{Data Collection Instruments}

In the research, "Foreign Language Learning Anxiety Scale" (FLLAS) (Baş, 2013b) was used as the data collection instrument. In addition to this, a demographic information part, which included the students' gender, current educational status, educational status of their parents (father and mother), and monthly income of their families, was added at the beginning of the scale to obtain their demographic features.

\subsubsection{Foreign Language Learning Anxiety Scale}

In this research, the FLLAS developed by Baş (2013b) was used. The scale has 3 factors (personality, communication, and evaluation) and 27 items. The factor loading of the scale ranged from .817 to .433 and total item correlation values were found to be between .67 and .41 . Moreover, the reliability coefficient of the scale was.93, and Spearman-Brown split half correlation was .83. Finally, Cronbach's Alpha reliability coefficients of the factors were calculated between .89 to .83 (Baş, 2013b).

\subsection{Data Analysis}

In data analysis, first of all, descriptive statistics such as mean scores and standard deviations were calculated based on the students' responses to "Foreign Language Learning Anxiety Scale". In addition to this, whether FLL anxiety level of students change according to some demographic features was examined. For the comparisons on gender and current educational status, independent samples $t$-test was used. On the other hand, one-way ANOVA was used for the comparison according to educational status of parents (father and mother) and monthly income of families. To identify the source of the difference, Tukey-HSD was used for the significant $F$ values found as a result of one-way ANOVA analysis.

\section{Findings}

This section presented the results regarding the FLL anxiety of students studying at high school and university and comparisons in terms of gender, current educational status, educational status of their parents (father and mother), and monthly income of their families. 
Baş, G., \& Özcan, M. (2018). Foreign language learning anxiety: A comparison between high school and university students. Journal of Human Sciences, 15(3), 1584-1596. doi:10.14687/ihs.v15i3.4441

\subsection{Descriptive Findings}

In this part of the research, descriptive findings in terms of high school and university students' FLL anxiety were given briefly. Thus, Table 1 presented the results on FLL anxiety level of students studying at high school and university.

Table 1.

FLL anxiety level of high school and university students

\begin{tabular}{lcccccc}
\hline Variables & \multicolumn{2}{c}{ High school $(n=333)$} & & \multicolumn{2}{c}{ University $(n=341)$} \\
& $M$ & $S D$ & & & \multicolumn{2}{c}{$S D$} \\
\cline { 2 - 3 } \cline { 5 - 6 } Personality & 38.71 & 6.01 & & 26.44 & 3.22 \\
Communication & 39.43 & 7.38 & & 30.69 & 4.64 \\
Evaluation & 31.69 & 6.11 & & 25.98 & 4.63 \\
\hline
\end{tabular}

The results (Table 1) showed that FLL anxiety of high school students was higher in the construct of "communication" $(M=39.43, S D=7.38)$ than the constructs of "personality" $(M=$ $38.71, S D=6.01)$ and "evaluation" $(M=31.69, S D=6.11)$. On the other hand, it was seen that university students, like the ones at high school, experienced a higher level of FLL anxiety in the construct of "communication" $(M=30.69, S D=4.64)$ than the constructs of "personality" $(M=$ $26.44, S D=3.22)$ and "evaluation" $(M=25.98, S D=4.63)$. Figure 1 visualizes the FLL anxiety of high school and university students.

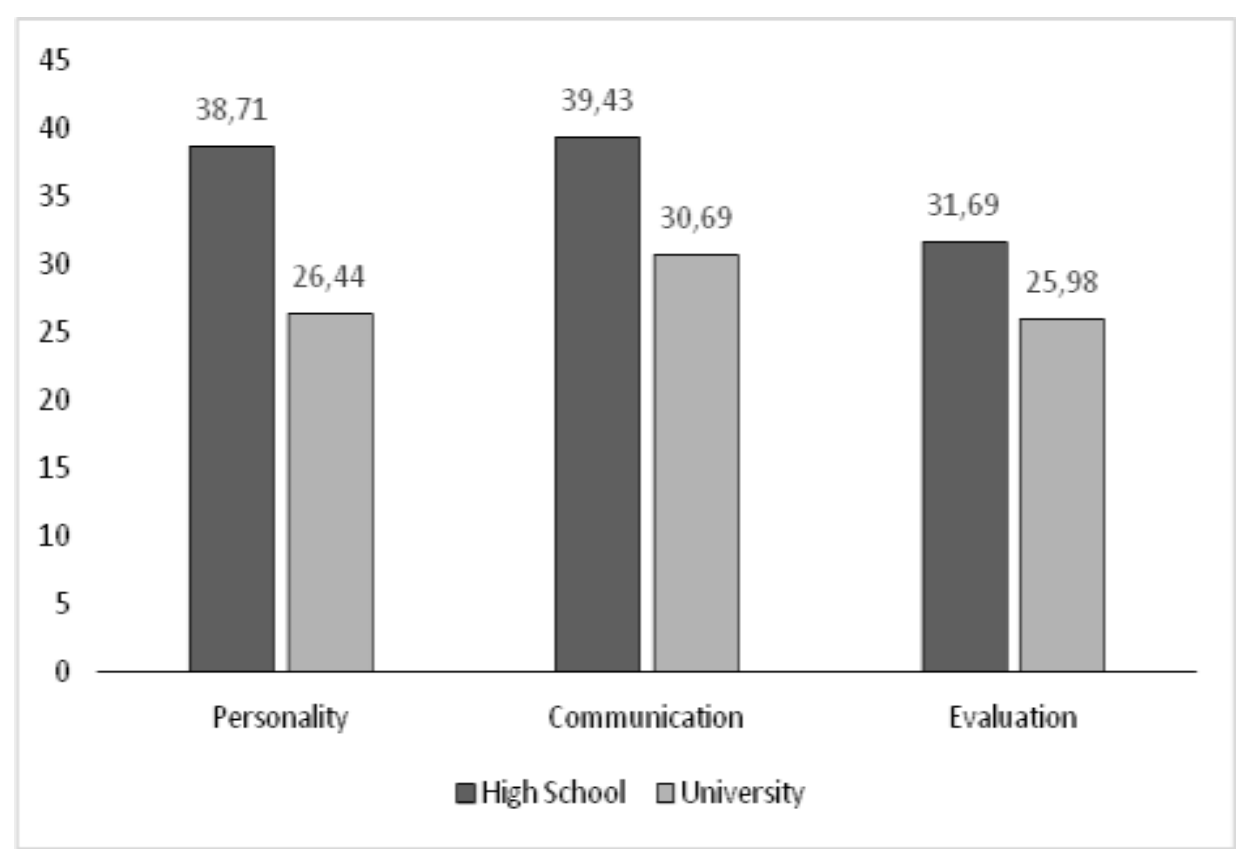

Figure 1. FLL anxiety levels of high school and university students

FLL anxiety of high school and university students was also presented in Figure 1. In the figure, the levels were shown based on the constructs of FLLAS.

\subsection{Examining the Foreign Language Learning Anxiety in Terms of Some Variables}

FLL anxiety of high school and university students according to gender, current educational status, educational status of their parents (father and mother) and monthly income of their families are presented below. 
Baş, G., \& Özcan, M. (2018). Foreign language learning anxiety: A comparison between high school and university students. Journal of Human Sciences, 15(3), 1584-1596. doi:10.14687/ihs.v15i3.4441

\subsubsection{Gender}

Table 2 presented the independent samples $t$-test results for comparison of FLL anxiety of high school and university students in terms of gender variable.

\begin{tabular}{|c|c|c|c|c|c|c|c|}
\hline \multirow[b]{2}{*}{ Gender } & \multicolumn{2}{|c|}{$\begin{array}{l}\text { High School } \\
\quad(n=333)\end{array}$} & \multicolumn{2}{|c|}{$\begin{array}{c}\text { University } \\
(n=341)\end{array}$} & \multirow[b]{2}{*}{$d f$} & \multirow[b]{2}{*}{$t$} & \multirow[b]{2}{*}{$p$} \\
\hline & $M$ & $S D$ & $M$ & $S D$ & & & \\
\hline \multicolumn{8}{|l|}{ Male $(n=266)$} \\
\hline Personality & 38.46 & 6.16 & 26.72 & 3.61 & \multirow{3}{*}{672} & -.160 & 0.873 \\
\hline Communication & 39.29 & 7.30 & 29.81 & 5.05 & & -1.617 & 0.106 \\
\hline Evaluation & 32.15 & 6.12 & 24.78 & 5.04 & & -1.513 & 0.131 \\
\hline \multicolumn{8}{|l|}{ Female $(n=408)$} \\
\hline Personality & 38.87 & 5.92 & 26.25 & 2.93 & \multirow{3}{*}{672} & -.160 & 0.873 \\
\hline Communication & 39.51 & 7.45 & 31.28 & 4.25 & & -1.617 & 0.106 \\
\hline Evaluation & 31.40 & 6.10 & 26.78 & 4.16 & & -1.513 & 0.131 \\
\hline
\end{tabular}

To compare the FLL anxiety of high school and university students in terms of their gender, independent samples $t$-test was used and the results were presented in Table 2 . The results indicated that that the anxiety level of students did not differ significantly in terms of their gender in the constructs of "personality" $(t(672)=-.160, p>0.05)$, "communication" $(t(672)=-1.617, p>$ $0.05)$ and "evaluation" $(t(672)=-1.513, p>0.05)$. Thus, it could be claimed that there was not a significant difference between genders in terms of the anxiety levels of the students.

\subsubsection{Current Educational Status}

The independent samples $t$-test was conducted to compare the anxiety of participating students in terms of their current educational status, and the results were given in Table 3.

\section{Table 3.}

Comparison of FLL anxiety in terms of their current educational status

\begin{tabular}{|c|c|c|c|c|c|c|c|}
\hline \multirow[b]{2}{*}{ Variables } & \multicolumn{2}{|c|}{$\begin{array}{l}\text { High School } \\
\quad(n=333)\end{array}$} & \multicolumn{2}{|c|}{$\begin{array}{l}\text { University } \\
(n=341)\end{array}$} & \multirow[b]{2}{*}{$d f$} & \multirow[b]{2}{*}{$t$} & \multirow[b]{2}{*}{$p$} \\
\hline & $M$ & $S D$ & $M$ & $S D$ & & & \\
\hline Personality & 38.61 & 6.06 & 26.39 & 3.15 & \multirow{3}{*}{672} & $32.937^{*}$ & 0.000 \\
\hline Communication & 39.33 & 7.41 & 30.68 & 4.62 & & $18.207 *$ & 0.000 \\
\hline Evaluation & 31.60 & 6.17 & 26.00 & 4.61 & & $13.362^{*}$ & 0.000 \\
\hline
\end{tabular}
${ }^{*} p<0.05$

The results showed that there was a statistically significant difference between high school and university students in terms of their FLL anxiety based on the constructs of "personality" $(t(672)=32.937, p<0.05)$, "communication" $(t(672)=18.207, p<0.05)$, and "evaluation" $(t(672)=$ 13.362, $p<0.05)$. It was also seen that high school students experienced a higher level of FLL anxiety in all constructs $\left(M_{\text {personaliy }}=38.61 ; M_{\text {communuication }}=39.33 ; M_{\text {evaluation }}=31.60\right)$ than university students. 
Baş, G., \& Özcan, M. (2018). Foreign language learning anxiety: A comparison between high school and university students. Journal of Human Sciences, 15(3), 1584-1596. doi:10.14687/ihs.v15i3.4441

\subsubsection{Educational Status of Father}

To find out whether educational status of fathers played a significant role on the FLL anxiety of high school and university students, one-way ANOVA analysis was conducted and the results were presented in Table 4.

\section{Table 4.}

Comparison of FLL anxiety in terns of educational status of father

\begin{tabular}{|c|c|c|c|c|c|c|c|}
\hline \multirow[b]{2}{*}{ Educational status } & \multicolumn{2}{|c|}{$\begin{array}{l}\text { High school } \\
(n=333)\end{array}$} & \multicolumn{2}{|c|}{$\begin{array}{l}\text { University } \\
(n=341) \\
\end{array}$} & \multirow[b]{2}{*}{$d f$} & \multirow[b]{2}{*}{$F$} & \multirow[b]{2}{*}{$p$} \\
\hline & $M$ & $S D$ & $M$ & $S D$ & & & \\
\hline \multicolumn{8}{|l|}{$\begin{array}{l}\text { Illiterate } \\
(n=42)\end{array}$} \\
\hline Personality & 38.09 & 7.26 & 25.95 & 3.94 & \multirow{3}{*}{$3-670$} & 0.196 & 0.899 \\
\hline Communication & 36.23 & 8.86 & 30.80 & 5.08 & & 1.933 & 0.123 \\
\hline Evaluation & 28.95 & 6.16 & 25.52 & 5.11 & & 1.469 & 0.333 \\
\hline \multicolumn{8}{|l|}{$\begin{array}{l}\text { Primary school } \\
(n=384)\end{array}$} \\
\hline Personality & 38.66 & 6.64 & 26.38 & 3.25 & \multirow{3}{*}{$3-670$} & 0.196 & 0.899 \\
\hline Communication & 40.28 & 7.21 & 30.96 & 4.52 & & 1.933 & 0.123 \\
\hline Evaluation & 32.05 & 6.36 & 26.11 & 4.56 & & 1.469 & 0.333 \\
\hline \multicolumn{8}{|l|}{$\begin{array}{l}\text { High school } \\
(n=178)\end{array}$} \\
\hline Personality & 39.11 & 4.11 & 26.72 & 2.86 & \multirow{3}{*}{$3-670$} & 0.196 & 0.899 \\
\hline Communication & 38.89 & 6.71 & 30.47 & 4.55 & & 1.933 & 0.123 \\
\hline Evaluation & 31.82 & 5.19 & 26.14 & 4.65 & & 1.469 & 0.333 \\
\hline \multicolumn{8}{|l|}{$\begin{array}{l}\text { University } \\
(n=70)\end{array}$} \\
\hline Personality & 38.29 & 5.84 & 26.36 & 3.57 & \multirow{3}{*}{$3-670$} & 0.196 & 0.899 \\
\hline Communication & 38.05 & 8.38 & 29.69 & 5.23 & & 1.933 & 0.123 \\
\hline Evaluation & 31.05 & 6.61 & 25.13 & 4.76 & & 1.469 & 0.333 \\
\hline
\end{tabular}

When the one-way ANOVA results were examined, it was seen that educational status of fathers did not have a statistically significant impact on the FLL anxiety level of both high school and university students based on the constructs of "personality" $(F(3-670)=0.196, p>0.05)$, "communication" $(F(3-670)=1.933, p>0.05)$, and "evaluation" $(F(3-670)=1.469, p>0.05)$.

\subsubsection{Educational Status of Mother}

FLL anxiety of high school and university students were also compared in terms of educational status of mothers. One-way ANOVA analysis was conducted to see the comparison and the results were presented in Table 5. 
Baş, G., \& Özcan, M. (2018). Foreign language learning anxiety: A comparison between high school and university students. Journal of Human Sciences, 15(3), 1584-1596. doi:10.14687/ihs.v15i3.4441

\section{Table 5.}

Comparison of FLL anxiety in terms of educational status of mother

\begin{tabular}{|c|c|c|c|c|c|c|c|}
\hline \multirow[b]{2}{*}{ Educational status } & \multicolumn{2}{|c|}{$\begin{array}{l}\text { High school } \\
(n=333)\end{array}$} & \multicolumn{2}{|c|}{$\begin{array}{c}\text { University } \\
(n=341)\end{array}$} & \multirow[b]{2}{*}{$d f$} & \multirow[b]{2}{*}{ F } & \multirow[b]{2}{*}{$p$} \\
\hline & M & $S D$ & $M$ & $S D$ & & & \\
\hline \multicolumn{8}{|l|}{$\begin{array}{l}\text { illiterate } \\
(n=84)\end{array}$} \\
\hline Personality & 39.21 & 5.72 & 27.47 & 4.52 & \multirow{3}{*}{$3-670$} & 0.599 & 0.616 \\
\hline Communication & 39.59 & 6.61 & 31.95 & 4.60 & & 1.040 & 0.374 \\
\hline Evaluation & 32.07 & 5.48 & 26.26 & 3.24 & & 0.870 & 0.456 \\
\hline \multicolumn{8}{|l|}{$\begin{array}{l}\text { Primary School } \\
(n=481)\end{array}$} \\
\hline Personality & 38.49 & 6.41 & 26.28 & 2.96 & \multirow{3}{*}{$3-670$} & 0.599 & 0.616 \\
\hline Communication & 39.32 & 7.62 & 30.74 & 4.75 & & 1.040 & 0.374 \\
\hline Evaluation & 31.38 & 6.40 & 25.99 & 4.71 & & 0.870 & 0.456 \\
\hline \multicolumn{8}{|l|}{$\begin{array}{l}\text { High school } \\
(n=94)\end{array}$} \\
\hline Personality & 38.88 & 4.20 & 26.30 & 3.11 & \multirow{3}{*}{$3-670$} & 0.599 & 0.616 \\
\hline Communication & 39.15 & 7.09 & 29.40 & 3.89 & & 1.040 & 0.374 \\
\hline Evaluation & 32.31 & 5.13 & 25.57 & 4.03 & & 0.870 & 0.456 \\
\hline \multicolumn{8}{|l|}{$\begin{array}{l}\text { University } \\
(n=15)\end{array}$} \\
\hline Personality & 41.71 & 2.42 & 26.62 & 3.24 & \multirow{3}{*}{$3-670$} & 0.599 & 0.616 \\
\hline Communication & 43.85 & 4.74 & 30.50 & 4.34 & & 1.040 & 0.374 \\
\hline Evaluation & 36.00 & 3.60 & 26.62 & 4.06 & & 0.870 & 0.456 \\
\hline
\end{tabular}
${ }^{*} p>0.05$

As it was seen, the results revealed that FLL anxiety of high school and university students differed significantly in terms of educational status of their mothers in all constructs; "personality" $(F(3-670)=0.599, p>0.05)$, "communication" $(F(3-670)=1.040, p>0.05)$, and "evaluation" ( $F(3-$ $670)=0.870, p>0.05)$.

\subsubsection{Monthly Income of Family}

Whether monthly income of the family played a significant role of FLL anxiety of high school and university students was investigated through one-way ANOVA analysis and the findings were presented in Table 6 . 
Baş, G., \& Özcan, M. (2018). Foreign language learning anxiety: A comparison between high school and university students. Journal of Human Sciences, 15(3), 1584-1596. doi:10.14687/ihs.v15i3.4441

\section{Table 6.}

Comparison of FLL anxiety in terms of monthly income of family

\begin{tabular}{|c|c|c|c|c|c|c|c|}
\hline \multirow[b]{2}{*}{ Monthly income } & \multicolumn{2}{|c|}{$\begin{array}{l}\text { High school } \\
(n=333)\end{array}$} & \multicolumn{2}{|c|}{$\begin{array}{c}\text { University } \\
(n=341)\end{array}$} & \multirow[b]{2}{*}{$d f$} & \multirow[b]{2}{*}{$F$} & \multirow[b]{2}{*}{$p$} \\
\hline & $M$ & $S D$ & $M$ & $S D$ & & & \\
\hline \multicolumn{8}{|l|}{$\begin{array}{l}\text { Under } 500 \text { TL } \\
(n=42)\end{array}$} \\
\hline Personality & 39.21 & 5.72 & 27.47 & 4.52 & \multirow{3}{*}{ 4-669 } & 0.134 & 0.970 \\
\hline Communication & 39.59 & 6.61 & 31.95 & 4.60 & & 0.526 & 0.717 \\
\hline Evaluation & 32.07 & 5.48 & 26.26 & 3.24 & & 0.768 & 0.546 \\
\hline \multicolumn{8}{|l|}{$\begin{array}{l}501-1000 \mathrm{TL} \\
(n=213)\end{array}$} \\
\hline Personality & 38.49 & 6.41 & 26.28 & 2.96 & \multirow{3}{*}{$4-669$} & 0.134 & 0.970 \\
\hline Communication & 39.32 & 7.62 & 30.74 & 4.75 & & 0.526 & 0.717 \\
\hline Evaluation & 31.38 & 6.40 & 25.99 & 4.71 & & 0.768 & 0.546 \\
\hline \multicolumn{8}{|l|}{$\begin{array}{l}1001-1500 \mathrm{TL} \\
(n=164)\end{array}$} \\
\hline Personality & 38.88 & 4.20 & 26.30 & 3.11 & \multirow{3}{*}{ 4-669 } & 0.134 & 0.970 \\
\hline Communication & 39.15 & 7.09 & 29.40 & 3.89 & & 0.526 & 0.717 \\
\hline Evaluation & 32.31 & 5.13 & 25.57 & 4.03 & & 0.768 & 0.546 \\
\hline \multicolumn{8}{|l|}{$\begin{array}{l}1501-2000 \mathrm{TL} \\
(n=117)\end{array}$} \\
\hline Personality & 41.71 & 2.42 & 26.62 & 3.24 & \multirow{3}{*}{$4-669$} & 0.134 & 0.970 \\
\hline Communication & 43.85 & 4.74 & 30.50 & 4.34 & & 0.526 & 0.717 \\
\hline Evaluation & 36.00 & 3.60 & 26.62 & 4.06 & & 0.768 & 0.546 \\
\hline \multicolumn{8}{|l|}{$\begin{array}{l}2001 \text { TL and over } \\
(n=138)\end{array}$} \\
\hline Personality & 41.71 & 2.42 & 26.62 & 3.24 & \multirow{3}{*}{$4-669$} & 0.134 & 0.970 \\
\hline Communication & 43.85 & 4.74 & 30.50 & 4.34 & & 0.526 & 0.717 \\
\hline Evaluation & 36.00 & 3.60 & 26.62 & 4.06 & & 0.768 & 0.546 \\
\hline
\end{tabular}

Based on the results of each construct as "personality" $(F(4-669)=0.134, p>0.05)$, "communication" $(F(4-669)=0.526, p>0.05)$, and "evaluation" $(F(4-669)=0.768, p>0.05)$, it can be claimed that there was not a statistically significant difference between FLL anxiety of high school and university students in terms of monthly income of students' families.

\section{Discussion and Conclusion}

The aim of this research was to reveal the FLL anxiety of high school and university students in terms of some variables such as gender, current educational status, educational status of parents (father and mother), and monthly income of families. 
Baş, G., \& Özcan, M. (2018). Foreign language learning anxiety: A comparison between high school and university students. Journal of Human Sciences, 15(3), 1584-1596. doi:10.14687/ihs.v15i3.4441

Firstly, this research examined whether FLL anxiety of high school and university students differed according to their gender. 266 male and 408 female students participated in this research. The results showed that there was not a statistically significant difference between male and female students in terms of their FLL anxiety. According to Alsowat (2016), gender is a significant factor in language learning, since it plays a critical role in foreign language learning process. As the previous research literature is reviewed, gender variable is seen to influence the level of foreign language anxiety among students. Unlike the current finding of this research, while some studies reported that female students have more FLL anxiety than male students (e.g., Arnaiz \& Guillen, 2012; Golchi, 2012; Mesri, 2012), some of them reported that male students have more FLL anxiety than the females (e.g., Awan, Azher, Anwar, \& Naz, 2010; Hussain, Shahid, \& Zaman, 2011; Lian \& Budin, 2014). Also, some other studies indicated that gender was an ineffective variable which might affect FLL anxiety in the classroom (e.g., Alsowat, 2016; Nahavandi \& Mukundan, 2013; Özütürk \& Hürsen, 2013; Wu, 2012), which confirm the current finding of the research. Therefore, although gender is considered as a significant factor in language learning (Alsowat, 2016), the research literature reports conflicting findings in terms of the role of gender playing in FLL anxiety (Yang, 2012).

The research was conducted in two groups of students studying at high school and university. When the difference between these two groups was examined, it was seen that high school students experienced more FLL anxiety than university students. As the research literature is reviewed, though it was seen that most studies on FLL anxiety included university students (e.g., Dewaele \& MacIntyre, 2014; Liu \& Ni, 2015; Onwuegbuzie, Bailey, \& Daley, 2000; Park \& French, 2013; Week \& Ferraro, 2011), very few of them was conducted with high school students (e.g., Dewaele \& MacIntyre, 2014; MacIntyre, Baker, Clement, \& Donovan, 2003). As Dewaele and MacIntyre (2014) reported, teenagers have the highest FLL anxiety followed by those in their twenties and pre-teens showing the lowest anxiety. On of the reasons for the finding obtained in the research may be that university students feel more independent and self-reliant in learning than high school students (Trang, Moni, \& Baldauf, 2012). Also, methods of teachers in using teaching English may be another reason that high school students have more FLL anxiety than university students. It is stated that teachers in the Turkish Education System (TES) continue to practice English language teaching with traditional methods (Demirpolat, 2015; Iş1k, 2008). Thus, the practice of English language teaching with traditional methods by teachers is considered to result in a higher level of FLL anxiety in high school students. Furthermore, tests may be another reason provoking FLL anxiety in high school students (Chan \& Wu, 2004; Jen, 2003). As the fear of exams, quizzes, and other assignments used to evaluate performance of students (Wu, 2010), test anxiety may play a painful role in learning a foreign language (Horwitz, Horwitz, \& Cope, 1986; MacIntyre \& Gardner 1991). High school students in Turkey are faced with many examinations in the education process starting from primary school (Sar1, Bilek, \& Çelik, 2018), resulting in considerable test anxiety (Arslan \& Aksekioğlu, 2017). Since the research literature reports a strong positive correlation between test anxiety and FLL anxiety (Salehi \& Marefat, 2014), test anxiety can be suggested to be one of the reasons provoking FLL anxiety of high school students, other than university students.

The results also showed that educational status of fathers did not have a significant impact on FLL anxiety students had. The research literature also reported that there was not a statistical significance among students in terms of their FLL anxiety according to father's education status (e.g., Awan et. al., 2010; Jin, de Bot, \& Keijzer, 2015; Öner \& Gedikoğlu, 2007), which confirmed the current finding of the research. According to Iwaniec (2016), parents' role is very important in language learning motivation of their children. Also, it was reported that as the educational status of fathers increase, they become more aware of the importance of the involvement process in their children (Poyraz, 2017). Although the perception of students in terms of their fathers' support in learning a language is not directly related to their performance in the classroom (Gardner, 1985) and does not have an impact on their attitudes toward learning a foreign language (İnal, İlke, \& 
Baş, G., \& Özcan, M. (2018). Foreign language learning anxiety: A comparison between high school and university students. Journal of Human Sciences, 15(3), 1584-1596. doi:10.14687/ihs.v15i3.4441

Saracaloğlu, 2005), it may be one of the sources of FLL anxiety (Chan \& Wu, 2004). Unlike the importance attributed to father's educational status in the literature, educational status of fathers was not a significant factor in students' FLL anxiety, meaning that there was a not difference between students with illiterate fathers and university graduate fathers. The underlying reason for this finding may be the fact that males work in a family and meet the financial responsibilities. In this sense, fathers cannot pay attention to the education of their children. For this reason, the assistance they can provide to their children for foreign language is limited. Thus, students do not think about the support of their father and this issue does not create any FLL anxiety.

On the other hand, unlike the literature (e.g., Öner \& Gedikoğlu, 2007), it was found in the current research that educational status of mothers was an influential factor in their children's FLL anxiety. In a research conducted by İnal, Evin, and Saracaloğlu (2005), mother educational status of students was found to be a very crucial factor in developing positive attitudes toward learning a foreign language, meaning that students with university graduate mothers have more positive attitudes toward learning a foreign language than students with illiterate mothers and students with mothers of primary school graduates. The reason for the finding obtained in the research is the fact that mothers are more interested in their children's education whether they work or not. An educated mother with knowledge of a foreign language will contribute to the education of her children more and gain their trust. A student trusting her mother will experience less FLL anxiety and have more support during his/her education. This support will affect the students positively throughout his/her education life.

According to the last findings of the research, although it is claimed that low socioeconomic status of families creates a handicapped situation for FLL anxiety of students (e.g., Khattak, Abbasi, Jamshed, \& Baig, 2011; Piechurska-Kuciel, 2016), it was revealed in the current research that monthly income of families did not play a significant role on students' FLL anxiety. As a result of this, it could be claimed that the level of FLL anxiety students experienced while learning a foreign language was not influenced by the financial status of their families. This finding is in line with the findings of the research literature (e.g., Jin, de Bot, and Keijzer, 2015; Wilson, 2006), which revealed that monthly income of families did not have a significant impact on students' FLL anxiety. In other words, students' FLL anxiety does not change according to monthly income of families, meaning that families with high or low monthly income do not have a significant impact on the level of FLL anxiety their children experience in the classroom. Therefore, it could be claimed that monthly income of families does not contribute significantly to their children's FLL anxiety. It can be suggested that even though monthly income of families may be a crucial factor for students to buy the necessary materials or taking extra courses for learning a foreign language, it is considered not to be an important factor influencing FLL anxiety of students. Since FLL anxiety is a universal phenomenon among students, students having low and high monthly income families can experience this universal phenomenon in a similar way in the classroom, that is, FLL anxiety is not a problem of money, but it is a problem of, as in MacIntyre and Gardner's (1994) words, a feeling of tension and apprehension in learning a foreign language.

In conclusion, this research examined FLL anxiety of high school and university students in terms of some variables such as gender, current education status, high school type, parents' (father and mother) educational status, and monthly income of families. Firstly, it was found in the research that gender, educational status of fathers and monthly income of families were not significant factors in FLL anxiety of students. However, educational status of mothers, current educational status, and the type of high school was graduated/would graduate from were found to be significant factors in explaining FLL anxiety of students. 
Baş, G., \& Özcan, M. (2018). Foreign language learning anxiety: A comparison between high school and university students. Journal of Human Sciences, 15(3), 1584-1596. doi:10.14687/ihs.v15i3.4441

\section{References}

Akpur, U. (2005). The effects of learned helplessness and state-trait anxiety levels on students' English academic achievement. Unpublished master's thesis, Yildız Teknik University, Turkey.

Allwright, D., \& Bailey K. M. (1991). Focus on the language classroom: An introduction to classroom research for language teachers. Cambridge: Cambridge University Press.

Alsowat, H. H. (2016). Foreign language anxiety in higher education: A practical framework for reducing FLA. European Scientific Journal, 12(7), 193-220.

Arnaiz, P., \& Guillen, F. (2012). Foreign language anxiety in a Spanish university setting: Interpersonal differences. Revista-Psicodidactica, 17(1), 5-26.

Arslan, Ü., \& Aksekioğlu, B. (2017). Investigating high school students' test anxiety levels in terms of various variables. Journal of Human Sciences, 14(4), 4884-4897.

Awan, R., Azher, M., Anwar, M., \& Naz, A. (2010). An investigation of foreign language classroom anxiety and its relationship with students' achievement. Journal of College Teaching and Learning, 7(11), 33-40.

Aydin, B. (1999). A study of sources of foreign language classroom anxiety in speaking and writing classes. Unpublished doctoral dissertation. Anadolu University, Turkey.

Bailey, K. (1983). Competitiveness and anxiety in adult second language learning. In H. W. Seliger \& M. H. Long (Eds.), Classroom oriented research in language acquisition (pp. 67-102). New York: Newbury House.

Baş, G. (2014). Foreign language anxiety in high school students: A qualitative study. Pamukkkale Üniversitesi Eg̈itim Fakültesi Dergisi, 36, 101-119.

Baş, G. (2013a). Correlation between foreign language anxiety with attitudes towards English course and academic success of high school students. Atatürk Üniversitesi Kazım Karabekir Eğitim Fakültesi Dergisi, 27, 127-145.

Baş, G. (2013b). Foreign language learning anxiety scale: A study on its validity and reliability. Journal of Turkish Social Research, 17(2), 49-68.

Batumlu, D. Z. U. (2006). The effect of foreign language anxiety of YTU preparatory school students on their success in English. Unpublished master's thesis, Y1ldız Teknik University, Istanbul.

Chan, D., \& Wu, G. (2004). A study of foreign language anxiety of EFL elementary school students in Taipei county. Journal of National Taipei Teachers College, 17(2), 287-320.

Cheng, Y. S., Horwitz, E. K., \& Shallert, D. L. (1999). Language anxiety: Differentiating writing and speaking components. Language Learning, 49, 417-446.

Dalkiliç, N. (2001). An investigation into the role of anxiety in second language learning. Unpublished doctoral dissertation, Çukurova University, Adana.

Demirpolat, B. C. (2015). Türkiye'nin yabanc dil ögretimiyle imtihan: Sorunlar ve çözüm önerileri. İstanbul: SETA Siyaset, Ekonomi ve Toplum Araştırmaları Vakfi.

Dewaele, J-M., \& MacIntyre, P. D. (2014). The two faces of Janus? Anxiety and enjoyment in the foreign language classroom. Studies in Second Language Learning and Teaching, 4(2), 237-272.

Ellis, R., \& Rathbone, M. (1987). The acquisition of German in a classroom context. London: Ealing College of Higher Education.

Fraenkel, J. R., \& Wallen, N. E. (2000). How to design and evaluate research in education. New York: McGraw-Hill.

Gardner, R. C., Day, J. B., \& Maclntyre, P. O. (1992). Integrative motivation, induced anxiety, and language learning in a controlled environment. Studies in Second Language Learning, 14,197214.

Gardner, R. C. (1985). Social psychology and second language learning: The role of attitudes and motivation. London: Edward Arnold.

Gardner, R. C., Smythe, P. C., Clément, R., \& Gliksman, L. (1976). Second language learning: A social-psychological perspective. Canadian Modern Language Review, 32, 198-213. 
Baş, G., \& Özcan, M. (2018). Foreign language learning anxiety: A comparison between high school and university students. Journal of Human Sciences, 15(3), 1584-1596. doi:10.14687/ihs.v15i3.4441

Golchi, M. (2012). Listening anxiety and its relationship with listening strategy use and listening comprehension among Iranian IELTS learners. International Journal of English Linguistics, 2(4), $115-128$.

Gülsün, R. (1997). An analysis of the relationship between learners' foreign language classroom anxiety and achievement in learning English as a foreign language in the freshman classes at the university of Gaziantep. Unpublished master's thesis, Gaziantep University, Turkey.

Horwitz, E. K., Horwitz, M. B., \& Cope, J. A. (1986). Foreign language classroom anxiety. Modern Language Journal, 70, 125-132.

Hussain, M., Shahid, S., \& Zaman, A. (2011). Anxiety and attitude of secondary school students towards foreign language learning. Procedia - Social and Behavioral Sciences, 29, 583-590.

Işık, A. (2008). Yabanc1 dil eğitimindeki yanlışlar nereden kaynaklanıyor? Journal of Language and Linguistic Studies, 4(2), 15-26.

İnal, S., İlke, İ., \& Saracaloğlu, A. S. (2005). The relation between students' attitudes towards foreign language and foreign language achievement. Dil Dergisi, 130, 37-52.

Iwaniec, J. (2016, August). Parents and their role in language learning motivation. Paper presented at the European Second Language Association Conference, University of Jyväskylä.

Jen, C. (2003). Anxiety in English language classrooms: An investigation of Taiwanese secondary school students' foreign language anxiety in four classroom contexts. Unpublished master's thesis, University of Bristol, UK.

Jin, Y. X., De Bot, K., \& Keijzer, M. (2015). Factors associated with foreign language anxiety : A study of Chinese university learners of Japanese and English. Dutch Journal of Applied Linguistics, 4, 67-85.

Karasar, N. (2005). Bilimsel arastırma yöntemi (15th ed.). Ankara: Nobel Yayın Dağıtım.

Khattak, Z., Abbasi, M., Jamshed, T., \& Baig, M. (2011). An investigation into the causes of English language learning anxiety in students at AWKUM. Language in India, 11(5), 489-497.

Koch, A. S., \& Terrell, T. D. (1991). Affective reactions of foreign language students to natural approach activities and teaching techniques. In E. K. Horwitz \& D. J. Young (Eds.), Language anxiety: From theory and research to classroom implications (pp. 109-126). Englewood Cliffs, NJ: Prentice-Hall.

Krashen, S. D. (1985). Applications of psycholinguistic research to the classroom. C. James (Ed.), Practical applications of research in foreign language teaching (pp. 51-66). Lincolnwood, IL: National Textbook.

Lian, L., \& Budin, M. (2014). Investigating the relationship between English language anxiety and the achievement of school based oral English test among Malaysian form four students. International Journal of Learning, Teaching, and Educational Research, 2(1), 67-79.

Liu, M., \& Ni, H. (2015). Chinese university EFL learners' foreign language writing anxiety: Pattern, effect and causes. English Language Teaching, 8(3), 46-58.

MacIntyre, P. D., Baker, S. C., Clément, R., \& Donovan, L. A. (2003). Sex and age effects on willingness to communicate, anxiety, perceived competence, and L2 motivation among junior high school French immersion students. Language Learning, 53(S1), 137-166.

MacIntyre, P. D., \& Gardner, R. C. (1991). Language anxiety: Its relationship to the anxieties and to processing in native and second languages. Language Learning, 41(4), 513-534.

Mesri, F. (2012). The relationship between gender and Iranian EFL learners' foreign language classroom anxiety (FLCA). International Journal of Academic Research in Business and Social Sciences, 2(6), 147-156.

Nahavandi, N., \& Mukundan, J. (2013). Foreign language learning anxiety among Iranian EFL learners along gender and different proficiency levels. Language in India, 13(1), 133-161.

Onwuegbuzie, A. J., Bailey, P., \& Daley, C. E. (2000). Cognitive, affective, personality, and demographic predictors of foreign-language achievement. The Journal of Educational Research, 94(1), 3-15. 
Baş, G., \& Özcan, M. (2018). Foreign language learning anxiety: A comparison between high school and university students. Journal of Human Sciences, 15(3), 1584-1596. doi:10.14687/ihs.v15i3.4441

Oya, T., Manola, E., \& Greenwood J. (2004). The influence of personality and anxiety on the oral performance of Japanese speakers of English. Applied Cognitive Psychology, 18, 841-855.

Öner, G., \& Gedikoğlu, T. (2007). Foreign language anxiety affecting learning English of secondary school students in Gaziantep. Gaziantep Üniversitesi Sosyal Bilimler Dergisi, 6(2), 144-155.

Özütürk, G., \& Hürsen, Ç. (2013). Determination of English language learning anxiety in EFL classrooms. Procedia-Social and Behavioral Sciences, 84, 1899-1907.

Park, G., \& French, B. F. (2013). Gender differences in the foreign language classroom anxiety scale. System, 41(2), 462-471.

Piechurska-Kuciel, E. (2016). Economic strain and foreign language attainment: A Polish perspective. Paper presented at the 21st International Symposium on Theoretical and Applied Linguistics, Thessaloniki, Greece.

Price, M. L. (1991). The subjective experience of foreign language anxiety: Interviews with highly anxious students. In E. K. Horwitz \& D. J. Young (Eds.), Language anxiety: From theory and research to classroom implications (pp. 87-97). Englewood Cliffs, NJ: Prentice-Hall.

Price, M. L. (1988). Anxiety and the foreign language learner: Correlates of foreign language anxiety. Unpublished doctoral dissertation, The University of Texas at Austin, Austin, Texas.

Poyraz, E. (2017). The effects of parental involvement in English language learning of secondary school students. ELT Research Journal, 6(3), 250-275.

Riasati, M. J. (2011). Language learning anxiety from EFL learners' perspective. Middle-East Journal of Scientific Research, 7(6), 907-914.

Sarı, S. A., Bilek, G., \& Çelik, E. (2018). Test anxiety and self-esteem in senior high school students: A cross sectional study. Nordic Journal of Psychiatry, 72(2), 84-88.

Salehi, M., \& Marefat, F. (2014). The effects of foreign language anxiety and test anxiety on foreign language test performance. Theory and Practice in Language Studies, 4(5), 931-940.

Sarıül, H. (2000). Trait anxiety and foreign language anxiety and their effects on learners' foreign language proficiency and achievement. Unpublished master's thesis, Boğaziçi University, Istanbul.

Sparks, R. L., \& Ganschow, L. (1991). Foreign language learning differences: Affective or native language aptitude differences? Modern Language Journal, 75, 3-16.

Trang, T. T. T., Moni, K., \& Baldauf, R. B. (2012). Foreign language anxiety and its effects on students' determination to study English: To abandon or not to abandon? TESOL in Context, 3, 1-14.

Von Wörde, R. (1998). Students' perspectives on foreign language anxiety. Inquiry, 8(1), 1-15.

Week, M., \& Ferraro, F. (2011). Correlation between foreign language anxiety and gender. Psychology Journal, 8(1), 40-47.

Wilson, J. T. S. (2006). Anxiety in learning English as a foreign language: Its associations with student variables, with overall proficiency, and with performance on an oral test. Unpublished doctoral dissertation, University of Granada, Spain.

Wu, H. (2012). Anxiety and reading comprehension performance in English as a foreign language. Asian EFL Journal, 13(2), 273-307.

Wu, K. (2010). The relationship between language learners' anxiety and learning strategy in the CLT classrooms. International Education Studies, 3(1), 174-191.

Yang, H. (2012). Language anxiety: From the classroom to the community. English Teaching and Learning, 36(4), 1-36.

Young, D. J. (1992). Language anxiety from the foreign languages specialist's perspective: Interviews with Krashen, Omaggio, Hadley, Terrell, and Rardin. Foreign Language Annals, 25, 157-172.

Young, D. J. (1990). An investigation of students' perspectives on anxiety and speaking. Foreign Language Annals, 23, 539-553. 